\title{
Genetic regulation of bone mass and susceptibility to osteoporosis
}

\author{
Stuart H. Ralston ${ }^{1,3}$ and Benoit de Crombrugghe ${ }^{2}$ \\ ${ }^{1}$ Rheumatic Diseases Unit, Molecular Medicine Centre, Western General Hospital, Edinburgh EH4 2XU, United Kingdom; \\ ${ }^{2}$ Department of Molecular Genetics, M.D. Anderson Cancer Center, University of Texas, Houston, Texas 77030, USA
}

\begin{abstract}
Osteoporosis is a common disease with a strong genetic component characterized by reduced bone mass and increased risk of fragility fractures. Twin and family studies have shown that the heritability of bone mineral density (BMD) and other determinants of fracture risksuch as ultrasound properties of bone, skeletal geometry, and bone turnover-is high, although heritability of fracture is modest. Many different genetic variants of modest effect size are likely to contribute to the regulation of these phenotypes by interacting with environmental factors such as diet and exercise. Linkage studies in rare Mendelian bone diseases have identified several previously unknown genes that play key roles in regulating bone mass and bone turnover. In many instances, subtle polymorphisms in these genes have also been found to regulate $B M D$ in the general population. Although there has been extensive progress in identifying the genetic variants that regulate susceptibility to osteoporosis, most of the genes and genetic variants that regulate bone mass and susceptibility to osteoporosis remain to be discovered.
\end{abstract}

Osteoporosis is characterized by reduced bone mass, alterations in the microarchitecture of bone tissue, reduced bone strength, and an increased risk of fracture (Kanis et al. 1994). Osteoporosis is a common condition that affects up to $30 \%$ of women and $12 \%$ of men at some point in life. The prevalence of osteoporosis increases with age due to an imbalance in the rate at which bone is removed and replaced during the bone remodeling cycle, which is an important physiological process that is essential for maintenance of a healthy skeleton. Many factors influence the risk of osteoporosis-including diet, physical activity, medication use, and coexisting diseases-but one of the most important clinical risk factors is a positive family history, emphasizing the importance of genetics in the pathogenesis of osteoporosis. In this article, we first review the evidence for a genetic

[Keywords: Human molecular genetics; linkage; osteoporosis; association studies]

${ }^{3}$ Corresponding author.

E-MAIL stuart.ralston@ed.ac.uk; FAX 44-131-651-1085.

Article is online at http://www.genesdev.org/cgi/doi/10.1101/gad.1449506. contribution to osteoporosis and related phenotypes, and discuss the mechanisms by which mutations and polymorphisms in genes that regulate susceptibility to osteoporosis affect major signaling pathways in bone.

\section{Genetic influences on osteoporosis}

Genetic factors have long been recognized as playing an important role in the pathogenesis of osteoporosis. Evidence from twin and family studies suggests that between $50 \%$ and $85 \%$ of the variance in peak bone mass is genetically determined, depending on skeletal site and the age of the subjects studied (Smith et al. 1973; Pocock et al. 1987; Krall and Dawson-Hughes 1993; Gueguen et al. 1995). Heritability studies have also shown evidence of significant genetic effects on other key determinants of osteoporotic fracture risk, including quantitative ultrasound properties of bone (Arden et al. 1996), femoral neck geometry (Arden et al. 1996), muscle strength (Arden and Spector 1997), bone turnover markers (Hunter et al. 2001), and body mass index (Kaprio et al. 1995). The role of genetic factors in the pathogenesis of bone loss is less clear. One of the most important determinants of bone loss in women is estrogen deficiency at menopause, and previous studies have indicated that age at menopause is genetically determined (Snieder et al. 1998). However, studies on the genetic contribution to age-related bone loss have yielded mixed results. In one study, analysis of axial bone loss in a cohort of male and female twins showed evidence for a genetic contribution to bone loss (Kelly et al. 1993), but in another study of male twins, no such evidence was observed over a 16-yr follow up period (Christian et al. 1989). Further work is clearly required to determine whether bone loss has a heritable component. Conflicting results have also been reported with regard to the heritability of fracture, which is the most important clinical complication of osteoporosis. Family history of fracture has been shown in several studies to be a risk factor for fractures independently of bone mineral density (BMD) (Cummings et al. 1995; Torgerson et al. 1996) and, in keeping with this, several investigators have reported that fracture may also have a heritable component. Studies of post-menopausal 
women and their first-degree relatives from the United States (Deng et al. 2000) showed that the heritability of wrist fracture was $\sim 25 \%$, whereas similar studies in a cohort of female twins from the United Kingdom suggested that the heritability of wrist fracture may be as much as $54 \%$ (Andrew et al. 2005). Interestingly, the heritable component of wrist fracture in both of these studies seemed largely independent of BMD, suggesting that predisposition may have been mediated through genetic influences on bone turnover, and bone geometry or nonskeletal factors such as cognitive function, neuromuscular control, visual acuity, or other factors related to the risk of falling. In contrast to this work, however, another heritability study of elderly twins from Finland showed little evidence to suggest that fractures were heritable (Kannus et al. 1999). These divergent results are probably explained by the fact that the heritability of fracture decreases with age as environmental factors become more important. This was elegantly demonstrated in a large study of Swedish twins that showed that the heritability of hip fracture was high among those under the age of $65(\sim 68 \%)$, but dropped off rapidly with age to reach a value of almost zero by the eighth decade (Michaelsson et al. 2005). This illustrates that identifying genes that are related to risk factors for osteoporosis such as BMD does not necessarily mean that these will influence the risk of fracture.

It is currently believed that in the general population, genetic influences on BMD and the other phenotypes mentioned above are polygenic in nature and are mediated by the influence of several genetic variants, each of modest effect size, and their interaction with environmental factors. It is important to note, however, that severe osteoporosis and fragility fractures or unusually high bone mass (HBM) can also be an important feature of rare diseases that are primarily genetic in nature and are inherited in a classical Mendelian manner. Such diseases include osteopetrosis, sclerosing bone dysplasias, osteogenesis imperfecta, osteoporosis-pseudoglioma syndrome (OPPS), and osteoporotic syndromes associated with inactivating mutations of the estrogen receptor $\alpha$ and aromatase genes (Bilezikian et al. 1998; Janssens and Van Hul 2002; Van Wesenbeeck et al. 2003; Balemans et al. 2005). Although these diseases are rare, increasing evidence suggests that subtle polymorphic variations in genes that are mutated in these disorders also regulate $\mathrm{BMD}$ in the general population.

\section{Identifying osteoporosis genes}

Several approaches have been employed to try to identify the genes that regulate susceptibility to osteoporosis (Fig. 1), and these are discussed in more detail below.

\section{Association studies}

Association studies have been widely used in the field of osteoporosis genetics. These studies typically involve identifying polymorphisms of a particular candidate gene and relating alleles to BMD or osteoporotic fractures in a population-based study or a case-control study. Recently, however, it has also become possible to perform association studies on a genome-wide basis by analyzing a large number of closely spaced single-nucleotide polymorphisms (SNPs) spread randomly across the genome (Cardon and Abecasis 2003). The rationale for these studies is that these SNPs will be in linkage disequilibrium with causal variants in genes that predispose to the disease under study. Classical association studies typically involve choosing a candidate gene that is known to have effects on bone metabolism on the basis of knowledge about skeletal physiology or bone biology. Genes that are mutated in rare monogenic bone diseases have also proved to be a rich source of polymorphisms that regulate BMD in the normal population (Grant et al. 1996; Ferrari et al. 2004; Sobacchi et al. 2004; Pettersson et al. 2005). Association studies are relatively easy to perform and can be powered to detect small effects, but spurious results are often reported due to confounding factors, small sample size, and population stratification (Ioannidis 2003). In view of this, metaanalysis has been increasingly used to estimate the true size of the effect of polymorphisms that have been implicated in the pathogenesis of complex diseases (Lohmueller et al. 2003).

\section{Linkage analysis in humans}

Linkage studies are a tried and tested way of identifying genes responsible for monogenic diseases. Linkage studies have been spectacularly successful in identifying the genes that are responsible for rare, monogenic bone diseases characterized by abnormalities of bone mass such as osteopetrosis and sclerosing bone dysplasias (Janssens and Van Hul 2002; Balemans et al. 2005). Linkage analysis has also been applied to the identification of chromosomal regions that harbor genes that regulate quantitative traits such as bone mass, bone geometry, and ultrasound properties of bone in the normal population (Koller et al. 2003; Wilson et al. 2003, 2004; Ralston 2005). Linkage studies in osteoporosis classically involved genotyping a series of polymorphic microsatellite markers, typically spread at 10-cM intervals throughout the genome, and relating inheritance of alleles to the inheritance of bone mass within the family members. More recently, however, much denser maps of SNP have been used for linkage studies of complex disease, and initial experience suggests that these may be more powerful than classical microsatellite-based methods (Sawcer et al. 2004). A disadvantage of linkage studies in complex disease is that they have a relatively low statistical power to detect genes that have modest effects on the trait of interest, even when sample sizes of several thousand are used (Altmuller et al. 2001). Reflecting this fact, linkage studies of outbred human populations have so far met with limited success in terms of identification of genes that predispose to osteoporosis, whereas studies of isolated populations have been more successful in identifying genetic variants that predispose to osteoporosis 
Figure 1. Strategies for identifying genetic variants that contribute to osteoporosis and other complex disease. (Top) Linkage studies in families or sibling pairs are based on phenotyping members of extended families for the trait of interest (e.g., BMD) and relating inheritance of genetic markers in relation to inheritance of this phenotype. The phenotype can be dichotomized into affected (black symbols) or unaffected (white symbols), or analyzed as a quantitative trait. Studies of sibling pairs use a similar approach, but here evidence of allele sharing at loci of interest is sought in siblings who share the same phenotype. (Middle) Linkage studies in animals typically involve setting up an experimental cross between two inbred mouse strains with opposing phenotypes (e.g., high and low BMD). The F1 of offspring typically has intermediate BMD values due to inheritance of high BMD alleles from one parent and low BMD alleles from the other. Brother-sister mating of the F1 generation results in an F2 generation of offspring that has varying levels of BMD due to recombination between parental chromosomes. By conducting a genome search in the F2 generation, it is possible to relate inheritance of alleles from the parental strains to BMD, thereby localizing the genetic variants that regulate BMD. (Bottom) Association studies involve comparing frequency of alleles of candidate genes in unrelated subjects. (Left) This can take the form of a case-control study in which patients with osteoporosis or osteoporotic fractures (black symbols) are compared with unaffected subjects (white symbols). (Right) Association studies can also be performed in population-based studies of individuals who have varying BMD. Here, subjects are grouped according to carriage of alleles at the locus of interest and BMD values are compared in different genotype groups by analysis of variance.

(Styrkarsdottir et al. 2003) and other complex diseases (Gianfrancesco et al. 2003; Gretarsdottir et al. 2003).

\section{Model organisms}

Genetic linkage studies in experimental animals have long been used in the identification of genes responsible for complex traits (Rogers et al. 1997) and, over recent years, many such studies have been performed in an attempt to identify loci involved in the regulation of BMD in mice (Benes et al. 2000; Beamer et al. 2001; Orwoll et al. 2001). The approach used has been to cross inbred laboratory strains of mice with low and high bone density. By interbreeding offspring from the first generation (F1), a second generation (F2) of mice is established with varying levels of $\mathrm{BMD}$, because of segregation of the alleles that regulate BMD in the F2 offspring. A genomewide search is then performed in the F2 generation. This approach has several advantages: Environment can be carefully controlled, thus minimizing the influence of confounding factors, and large numbers of progeny can be generated, giving excellent statistical power. Genetic mapping studies in mice have identified a large number of loci that regulate BMD and have shown that the loci that regulate BMD are gender specific (Orwoll et al. 2001). Only one gene has been identified by positional cloning in inbred strains of mice to date (Klein et al. 2004), reflecting the fact that moving from QTL identification to gene identification is challenging. The reason for this is that the typical size of a QTL identified by genetic mapping within inbred strains of mice is $20-40$ $\mathrm{cM}$, but within this region, the genetic variants are essentially in complete linkage disequilibrium with each other, making identification of the causal variant difficult. The region of interest can be narrowed by generat- ing successive backcrosses against one of the parental strains, but this is time consuming and several generations of backcrossing are required to narrow the interval appreciably (Turner et al. 2003). Microarray analysis to define differentially regulated genes offers a potential approach to identifying causal genes, and this was sucessfully used by Klein et al. (2004) to identify a candidate gene (Alox15) within a mouse QTL that regulates BMD. Recent studies have indicated that polymorphic variation in a human homolog of this gene (Alox12) also regulates BMD in man (Ichikawa et al. 2006).

\section{Candidate genes for osteoporosis}

A very large number of genes have been identified as possible candidates for the regulation of bone mass and susceptibility to osteoporotic fractures. The most widely studied genes are listed in Table 1, and the points at which they influence calcium metabolism and regulation of bone turnover are illustrated in Figure 2. For many candidate genes, associations with BMD and other osteoporosis-related phenotypes have not been replicated, and in other cases, the mechanisms that underlie the association with BMD are poorly understood. In view of this, and because of space constraints, the following discussion will focus on the most widely studied candidate genes and those that impact on major signaling pathways in bone. A more comprehensive review of putative candidate genes for osteoporosis susceptibility has been published recently (Liu et al. 2003).

\section{Lipoprotein receptor-related protein 5 (LRP5)}

The LRP5 and LRP6 receptors are transmembrane proteins that function as coreceptors for canonical Wnt signaling. Wnt signaling plays an important role in several 
Table 1. Candidate genes for regulation of susceptibility to osteoporosis

\begin{tabular}{|c|c|}
\hline Hormones and receptors & $\begin{array}{l}\text { Bone matrix components } \\
\text { and degradative enzymes }\end{array}$ \\
\hline $\begin{array}{l}\text { Androgen receptor } \\
\text { Aromatase } \\
\text { Calcium-sensing receptor } \\
\text { Calcitonin receptor } \\
\text { Estrogen receptor } \alpha^{\mathrm{a}} \\
\text { Estrogen receptor } \beta \\
\text { Parathyroid receptor type } 1 \\
\text { Parathyroid hormone } \\
\text { Vitamin D receptor }\end{array}$ & $\begin{array}{l}\alpha \text { HS2 glycoprotein } \\
\text { Collagen type } 1 \propto \mathrm{I}^{\mathrm{a}} \\
\text { Osteocalcin } \\
\text { Proline lysine oxidase dehydrogenase-type collagenase }\end{array}$ \\
\hline Cytokines and receptors & Osteoblast regulatory factors \\
\hline $\begin{array}{l}\text { Interleukin-1 } \alpha \text { and } \beta \\
\text { Interleukin-1 receptor antagonist } \\
\text { Interleukin-6 } \\
\text { Tumor necrosis factor receptor } 2 \\
\text { Tumor necrosis factor }\end{array}$ & $\begin{array}{l}\text { Alox } 12 \text { and Alox } 15^{\mathrm{a}} \\
\text { Bone morphogenic protein } 2^{\mathrm{a}} \\
\text { Bone morphogenic protein } 4^{\mathrm{a}} \\
\text { Core-binding factor } \mathrm{A}^{\mathrm{a}} \\
\text { Insulin-like growth factor } 1 \\
\text { Sclerostin } \\
\text { Transforming growth factor } \beta^{\mathrm{a}} \\
\text { Lipoprotein-related receptors } 5 \text { and } 6^{\mathrm{a}} \\
\text { Peroxisome proliferator-activated receptor } \gamma\end{array}$ \\
\hline Miscellaneous & Osteoclast-related genes \\
\hline $\begin{array}{l}\text { Apolipoprotein E } \\
\text { Methylene tetrahydrofolate reductase } \\
\text { Klotho } \\
\text { HLA class II }\end{array}$ & 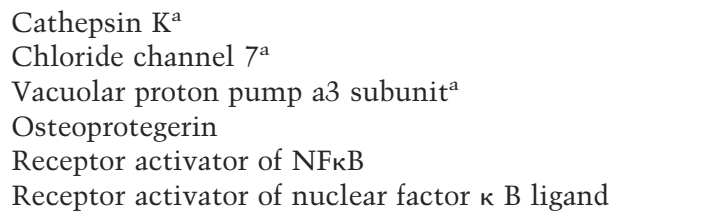 \\
\hline
\end{tabular}

${ }^{\mathrm{a}} \mathrm{Genes}$ discussed in this review.

key developmental processes, including cell fate decisions, limb patterning, and osteoblast and chondrocyte differentiation, and development of the central nervous system and other organs (Johnson et al. 2004). Transduction of the Wnt signal involves both LRP5 and LRP6, which form a receptor complex with Frizzled $(\mathrm{Fz})$ to activate the transcriptional activity of $\beta$-catenin, the downstream effector of canonical Wnt signaling (Cong et al. 2004). Regulation of signaling through the Wnt-LRP$\beta$-catenin pathway occurs at several levels, and key components of the pathway are illustrated in Figure 3. Extracellular inhibitors of Wnt signaling include the secreted Wnt antagonist; Dickkopf (Dkk) proteins, which bind to LRP5 and LRP6 and inhibit Wnt signaling (Bafico et al. 2001; Mao and Niehrs 2003); and a family of secreted frizzled-related proteins (Sfrps), which bind Wnt polypeptides and function as decoy receptors (Kawano and Kypta 2003). Dickkopf proteins can also down-regulate Wnt signaling by interacting with the transmembrane protein Kremen. As a result of this interaction, a complex is formed containing Dkk, Kremen, and the LRP5/6 proteins that is internalized, thereby down-regulating Wnt signaling (Mao et al. 2002).

The LRP5 pathway was discovered to be a key regulator of bone mass following linkage studies in two rare human diseases: OPPS, which is a recessively inherited condition characterized by severe, early onset osteopo- rosis and congenital blindness due to vitreous opacity (Gong et al. 1998), and the HBM syndrome that is an asymptomatic autosomal dominant disorder characterized by increased bone mineral density (Johnson et al. 1997). Both of these conditions were mapped to the same region of chromosome 11q12 in the late 1990s, and different mutations in the LRP5 gene were eventually identified as the cause of both disorders by positional cloning studies (Gong et al. 2001; Little et al. 2002). The HBM syndrome was found to be due to a heterozygous missense mutation causing a substitution of valine for glycine at codon 171 (G171V) of LRP5 within the first $\beta$-propeller motif of the molecule (Little et al. 2002). The OPPS syndrome was found to be due to different homozygous missense, nonsense, and frameshift mutations throughout the gene (Gong et al. 2001). Since these original reports, several additional missense mutations of LRP5 have been identified as a cause of HBM, and all of these cluster in or around the first $\beta$-propeller motif of LRP5 (Van Wesenbeeck et al. 2003).

The mutations that cause OPPS produce a truncated or nonfunctional LRP5 protein (Gong et al. 2001), and in accordance with this, complete inactivation of LRP5 by gene targeting in mice causes a low bone mass phenotype, which phenocopies the human disease OPPS (Kato et al. 2002). Analysis of bone histomorphometry in LRP5 knockout mice has shown that the low bone mass is a 
Figure 2. Candidate genes for susceptibility to osteoporosis. Most candidate genes for osteoporosis have been chosen for analysis on the basis that they play a role in regulating calcium metabolism or bone cell function. Circulating calciotropic hormones such as parathyroid hormone, estrogen, and $1,25(\mathrm{OH})_{2} \mathrm{D}_{3}$ regulate bone remodeling by interacting with receptors such as VDR, ESR1, and PTH receptor (PTHR1), which are expressed in target tissues in bone, kidney, and intestine. These systemic factors regulate expression of other regulator molecules within the bone microenvironment that regulate osteoblast and osteoclast differentiation and function. Candidate genes that have been studied in relation to osteoporosis are shown (see text for more details on the functional role of individual genes). (RANK) receptor activator of nuclear factor к B; (RANKL) RANK ligand; (OPG) osteoprotegerin; (CBFA1) core-binding factor 1; (PPAR $\gamma$ ) Peroxisome proliferator-activated receptor $\gamma_{;}(\mathrm{BMP} 2 / 4)$ bone morphogenic proteins 2 and 4; (TGF $\beta$ ) transforming growth factor $\beta_{\text {; }}$ (IGF1) insulin-like growth factor 1 ; (LRP5/6) lipoprotein receptor-related proteins 5 and 6 ; (SOST) Sclerostin; (CLCN7) chloride channel 7; (TCIRG1) Tcell immune regulator 1 ; (CATK) Cathepsin K. (CTR) Calcitonin receptor; $(\mathrm{AR})$ angrogen receptor.

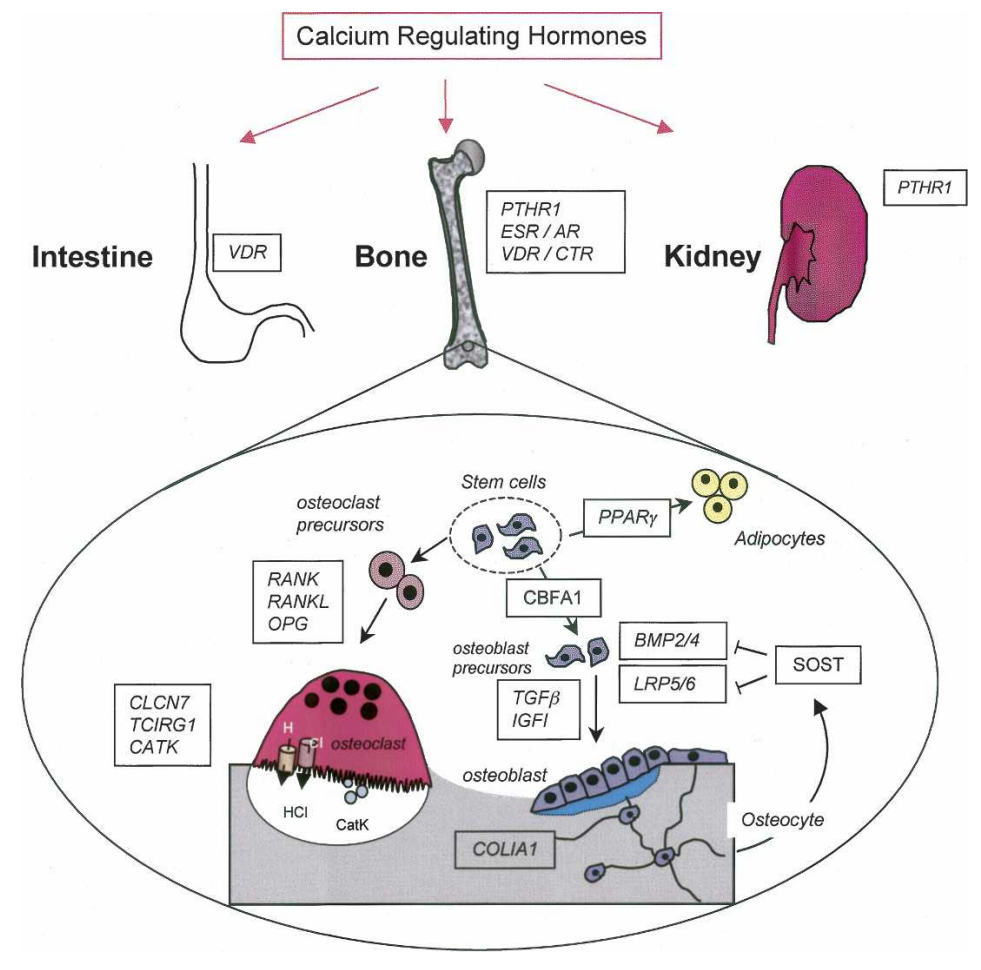

polymorphisms of LRP5 have been related to BMD and/ or osteoporotic fracture. Most of these studies have shown evidence of associations between LRP5 alleles and BMD and, interestingly, these associations have been particularly strong in men (Ferrari et al. 2004; Koh et al. 2004; Urano et al. 2004; van Meurs et al. 2006). Although many variants have been studied, the most likely functional candidate is an alanine-to-valine amino acid substitution at position 1330 (A1330V). The mechanism by which this variant might affect LRP5 signaling has not been investigated, but evidence of an interaction between the LRP5 A1330V variant and a coding polymorphism of LRP6 (1062V) has also been gained in the Rotterdam study (van Meurs et al. 2006), where polymorphisms of both genes were found to have an additive effect on fracture susceptibility. Interactions between LRP5 and LRP6 as regulators of BMD have also been observed in preclinical studies where skeletal phenotyping of mice with targeted inactivation of both receptors revealed allele dose-dependent deficits in BMD and limb formation, suggesting functional redundancy between these two genes in bone and limb development (Holmen et al. 2004).

In conclusion, the data so far indicate that genetic variation in LRP5 and possibly LRP6 plays an important role in regulation of bone mass and osteoporotic fractures in humans. Not only do rare mutations in the LRP5 gene play a major role in regulating $\mathrm{BMD}$, but more subtle polymorphisms also seem to regulate BMD in the normal population. Clearly, other components of this pathway-such as the Wnts, Dkks, Frizzled, Kremen, and Sfrps-now represent prime candidate genes for further study as potential genetic regulators of bone mass. 


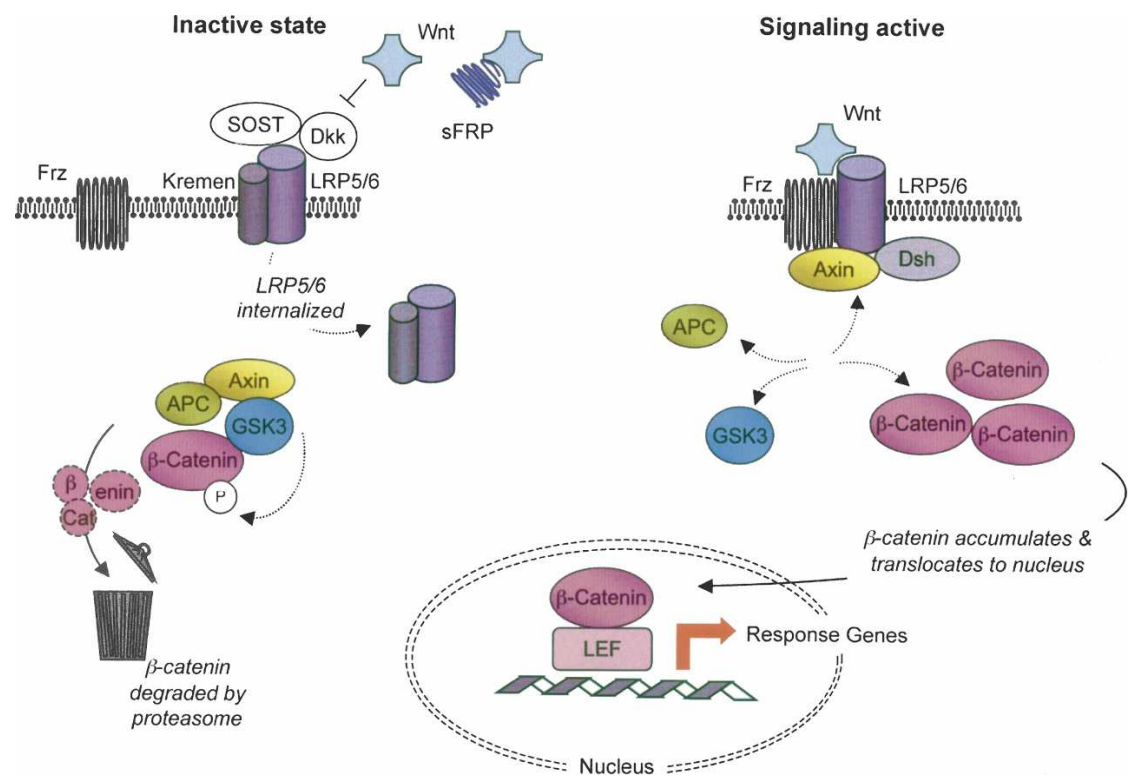

Figure 3. Components of the Wnt-LRP5 signaling pathway. The main components of the LRP5 signaling pathway are illustrated. (Left) In the unliganded state, $\beta$-catenin is held in a complex with Axin, APC, and GSK3. $\beta$-Catenin is phosphorylated by GSK3 while within this complex, and is targeted for proteasomal degradation. Both SOST and Dkk proteins complete with Wnt for receptor binding and, when Dkk is bound to LRP, the receptor associates with Kremen and the complex is internalized, thereby down-regulating LRP5 signaling. Sfrp prevent Wnt binding by acting as decoy receptors. (Right) In the presence of Wnt, Frizzled and LRP5 (or LRP6) come together to form a receptor complex and, on wnt binding, Axin is recruited to the intracellular domain of receptor complex with Dishevelled (Dsh), thereby disrupting the APC-Axin-GSK3$\beta$-catenin complex. As a result, $\beta$-catenin is no longer phosphorylated and accumulates in the cytosol as degradation is inhibited. The $\beta$-catenin translocates to the nucleus when it associates with LEF to activate expression of response genes that directly stimulate bone formation and indirectly inhibit bone resorption.

\section{Transforming growth factor TGF- $\beta 1$}

Members of the TGF- $\beta$ superfamily of related secreted polypeptides control critical cellular functions during embryonic development and also postnatally. Most attention has focused on TGF- $\beta 1$, which is encoded by the TGFB1 gene as a regulator of susceptibility to osteoporosis partly because it is particularly abundant in bone and has been shown to have effects on both osteoblast and osteoclast function in vitro (Massagué and Chen 2000). The receptor system for TGF $\beta$ molecules consists of two different high-affinity receptors, each of which contains an extracellular ligand-binding domain, a transmembrane domain, and an intracellular kinase domain. Upon TGF- $\beta$ binding, the type II receptor (TBR II) homodimer recruits a type I receptor (TBR I) homodimer to form a heterotetrameric receptor complex. Ligand binding to TBR II leads to phosphorylation of a glycine- and serine-rich domain in TBR I, which results in activation of signaling by this receptor. TBR I then phosphorylates Smad2 and Smad3, two so-called regulatory Smads or R-Smads, each of of which forms a complex with a unique common Smad, Smad4. These complexes translocate to the nucleus where they interact with other transcription factors and also, in the case of Smad3, with specific DNA sequences to activate a variety of downstream target genes. Inactivation of components of the TGF- $\beta$ pathway frequently results in embryonic lethality, but TGF- $\beta 1$-null mice develop generalized inflammation and decreased bone mass with a pronounced reduction of the number of osteoblasts (Geiser et al. 1998). In addition, Smad3-null mice show osteopenia, which is thought to be due to excessive late-phase osteoblast differentiation into osteocytes and concomitant apoptosis (Borton et al. 2001).
Polymorphisms of the TGFB1 gene have been extensively studied in relation to osteoporosis. One of the earliest studies was that of Langdahl et al. (1997), who identified a polymorphism within intron 4 of TGFB1 that was associated with severe osteoporosis. Subsequent work by the same group evaluated the relationship between several polymorphisms in TGFB1 and osteoporosis in a case-control study and identified an association between a different polymorphism in intron 5 and BMD (Langdahl et al. 2003). Other research has focused on polymorphisms in the promoter and first exon of TGFB1 in relation to BMD. One of these polymorphisms (a leucine-to-proline substitution at codon 10) has been associated with BMD in some populations (Yamada et al. 1999, 2001). Although genetic association studies have yielded somewhat conflicting results, definitive evidence that genetic variation in TGFB1 regulates bone mass in humans comes from the observation that Camurati-Engelmann (CED) disease is caused by mutations in TGFB1 (Janssens et al. 2000a; Kinoshita et al. 2000). CED is a rare autosomal dominant genetic disorder characterized by hyperostosis and sclerosis, especially affecting the diaphysis of long bones. Clinically, CED is characterized by radiological osteosclerosis, but affected patients also have increased markers of bone resorption, suggesting that bone resorption is elevated as well as bone formation (Hernandez et al. 1997). The causal gene for CED was mapped to chromosome 19q13 by linkage analysis (Ghadami et al. 2000; Janssens et al. 2000b), and then mutations in TGFB1 were identified as a cause using a positional candidate approach (Janssens et al. 2000a; Kinoshita et al. 2000). Most causal mutations lie within a region of the gene that encodes the latencyassociated peptide (LAP), although two other mutations have been identified in the signal peptide region, includ- 
ing a duplication of three leucine residues at codon 12 and a tyrosine-to-histidine amino acid change at codon 81. Following transcription and translation, the mature TGF $\beta 1$ peptide is cleaved from the LAP but is secreted from the cell in an inactive form as a dimer, which is bound noncovalently through disulfide bonds to LAP. These molecules can also form a larger covalent complex with a latent TGF- $\beta$-binding protein (LTBP). Activation of TGF $\beta 1$, which occurs outside the cell, can occur as the result of low $\mathrm{pH}$ or proteolytic activity and results in the release of the active TGF $\beta 1$ dimer from the LAP and other inhibitory molecules so that it can now directly interact with the TGF $\beta 1$ receptors (Janssens et al. 2003). Functional studies have shown that CED-causing mutations all act to increase SMAD-dependent TGF $\beta 1$ signaling, but by different mechanisms. Mutations in the LAP domain appear to inhibit formation of the disulfide bonds that link TGF $\beta 1$ to the LAP and cause increased release of biologically active TGF $\beta 1$. However, the other mutations in the signal peptide region prevent TGF $\beta 1$ secretion and result in intracellular accumulation of TGF- $\beta 1$ with stimulation of SMAD signaling by an intracrine mechanism that is poorly understood.

\section{Bone morphogenic proteins (BMPs)}

BMPs are part of the TGF $\beta$ superfamily of molecules. Signaling through BMP is regulated extracellularly by antagonists such as noggin and chordin (De Robertis and Kuroda 2004), and intracellularly by the Smad family of signaling proteins that act downstream from specific BMP receptors (Cao and Chen 2005). BMPs are strong candidate genes for regulation of bone mass, and naturally occurring mutations in various components of the BMP pathway result in defects of limb formation (Seemann et al. 2005). Recent studies indicate that polymorphic variation in members of the BMP family may be involved in regulation of bone mass and susceptibility to osteoporosis. A linkage study in Icelanders identified a locus for regulation of BMD on chromosome 20p12 (Styrkarsdottir et al. 2003), and subsequent positional cloning studies showed that the linkage signal was attributable in part to genetic variation in the BMP2 gene. A coding polymorphism was identified at codon 37 of the BMP2 protein, resulting in a substitution of alanine for a serine residue (Ser37Ala) that was overrepresented in Icelandic patients and in Danish patients with osteoporosis (Styrkarsdottir et al. 2003). The mechanisms by which this substitution affects BMP signaling to affect bone mass have not yet been investigated. Other workers have reported that common polymorphism, which causes an alanine-to-valine substitution at position 152 in the BMP4 protein (Ala152Val), is associated with low BMD (Ramesh et al. 2005). These association studies raise the possibility that polymorphic variation in members of the BMP family may be involved in osteoporosis, but further work will be required to confirm these observations and to study the mechanism by which the coding variants so far identified affect bone cell function and modulate bone mass.

\section{Sclerostin}

Sclerostin is a cysteine knot-containing protein that shares homology with the DAN family of BMP antagonists (Winkler et al. 2003; van Bezooijen et al. 2004). Sclerostin was first identified as a regulator of bone mass by genetic mapping studies in the sclerosing bone dysplasias Sclerosteosis and van Buchem disease. These are rare conditions with a similar phenotype that are inherited in an autosomal recessive manner. Both are characterized by progressive osteosclerosis mainly affecting the skull, mandible, and tubular bones of the extremities (Beighton et al. 1984). Sclerosteosis differs from van Buchem disease because it is more severe and is associated with hand malformations such as syndactyly, absent or dysplastic nails, and radial deviation of the terminal phalanges (Balemans et al. 2005). Both diseases were mapped to the same region of chromosome $17 \mathrm{q} 12$ 21 in the late 1990s (Van Hul et al. 1998; Balemans et al. 1999|, and positional cloning studies identified recessive loss-of-function mutations in Sclerostin (SOST) gene as the cause of Sclerosteosis in 2001 (Balemans et al. 2001; Brunkow et al. 2001). Interestingly, mutation screening of SOST in patients with van Buchem disease showed no mutations, but a homozygous $52-\mathrm{Kb}$ deletion was identified $35 \mathrm{~Kb}$ downstream from SOST as the cause of this condition (Balemans et al. 2002b). Subsequent work has shown that the deleted region contains highly conserved regulatory elements that play a key role in regulating SOST expression in bone (Loots et al. 2005). Although heterozygous carriers of SOST mutations are asymptomatic, they have significantly increased BMD, indicating that haploinsufficiency of SOST increases bone mass without apparently causing adverse effects (Gardner et al. 2005).

Polymorphisms of SOST have also been associated with BMD in some population-based studies. In the Rotterdam study (Uitterlinden et al. 2004), polymorphisms in the SOST promoter and the region deleted in van Buchem disease were both found to be associated with $\mathrm{BMD}$, and evidence was gained to suggest that the effect became more pronounced with increasing age. In another case-control study, SOST polymorphisms were not found to be associated with BMD (Balemans et al. 2002a), although this was a relatively small study and participants were of a younger age group than in the Rotterdam study.

In view of the structural similarity between SOST and other BMP antagonists, it was initially assumed that SOST regulates bone mass by affecting BMP signaling (Winkler et al. 2003). In keeping with this view was the observation that Sclerostin binds to both BMP5 and BMP6, competes with BMP6 for binding to the type I BMP receptor, and antagonizes the effects of BMP6 on Smad signaling (Winkler et al. 2003). Transgenic mice that overexpress SOST are osteopenic and have reduced bone formation, consistent with a model whereby SOST negatively regulates osteoblast function (Winkler et al. 2003). However, studies by van Bezooijen et al. (2004) showed that SOST was not a classical BMP antagonist, 
suggesting that it might interact with other signaling pathways to regulate bone formation. The mechanisms by which SOST inhibits bone formation has been clarified by recent studies, which have shown that SOST directly interacts with LRP5 and LRP6 and antagonizes Wnt signaling both in vitro and in vivo (Li et al. 2005; Semenov et al. 2005). However, other workers have proposed that the inhibitory effect of SOST on Wnt signaling is indirect and mediated through BMP production (Winkler et al. 2005). While further studies will be required to clarify the mechanisms by which SOST affects bone formation, it seems possible that the increased bone mass that results from SOST deficiency is mediated, at least in part, through the LRP5- $\beta$-catenin pathway.

\section{CBFA1}

The CBFA1 gene (also known as Runx2) plays an essential role in regulating osteoblast differentiation, since mice that are deficient in this transcription factor have complete absence of bone (Komori et al. 1997; Otto et al. 1997). Moreover, mice with haploinsufficiency of CBFA1 phenocopy the human syndrome of cleidocranial dysplasia (CCD), a skeletal disorder characterized by short stature, hypoplasia or aplasia of the clavicles, patent fontanelles, supernumerary teeth, and other defects in skeletal patterning and growth (Otto et al. 1997). The human syndrome of CCD is caused by various missense, nonsense, and frameshift mutations of CBFA1 (Lee et al. 1997; Mundlos et al. 1997; Quack et al. 1999). Some of these mutations have been shown to interfere with the DNA-binding activity of CBFA1, whereas others have been found to alter nuclear localization of the protein or to produce a mutant or truncated protein that is biologically inactive. In addition to these rare mutations, various polymorphisms have been identified in CBFA1 and some of these have been associated with bone mass in population-based studies (Vaughan et al. 2002, 2004; Doecke et al. 2006). The best functional candidates lie within the Runx2 promoter (Doecke et al. 2006) or within polyalanine and polyglutamine repeats in exon 1 . The polyalanine and polyglutamine repeats are of interest since they lie within one of the transactivation domains of Runx2. Various polymorphic variations have been identified in this region, including an 18-bp deletion that results in a polyalanine repeat of 11 residues (11 Ala) compared with the more common repeat of 17 residues (17 Ala). Various rare length variants within the polyglutamine repeat have also been identified, resulting in stretches of between 15 and 30 repeats. The strongest association with BMD has been observed with an anonymous polymorphism in the Ala repeat region (Vaughan et al. 2002, 2004), although it is thought that this might be due to linkage disequilibrium with polymorphisms in the promoter that have been shown to affect Runx2 transcription in reporter assays (Doecke et al. 2006). It is currently unclear whether the length variants in the polyalanine and polyglutamine tracts have functional importance, but this is an area of ongoing investigation.

\section{Cathepsin K}

Mutations in Cathepsin $\mathrm{K}$ are responsible for the rare syndrome of Pycnodysostosis, which is a rare recessive bone dysplasia characterized by osteosclerosis and short stature (Gelb et al. 1996). Various disease-causing mutations have been identified that result in production of either a truncated or a nonfunctional protein. Studies of more common polymorphic variants of Cathepsin $\mathrm{K}$ in relation to $\mathrm{BMD}$ regulation in the normal population have so far yielded negative results (Giraudeau et al. 2004).

\section{TCIRG1}

The TCIRG1 gene encodes the APT6i subunit of the osteoclast-specific proton pump, and various inactivating mutations in TCIRGI have been described that are responsible for a subset of patients with recessive osteopetrosis (Frattini et al. 2000). Recent work indicates that polymorphisms of TCIRG1 might also contribute to regulation of BMD in the normal population; a study by Frattini (Sobacchi et al. 2004) showed evidence of an association between a polymorphism affecting an AP1binding site in the TCIRG1 promoter and BMD in perimenopausal women. Functional studies need to be performed to identify the mechanisms that underlie this association, however, and to replicate the finding in other populations.

\section{CLCN7}

The CLCN7 gene encodes a chloride channel that is highly expressed in osteoclasts and is essential for acidification of the resorption lacuna. Homozygous inactivation mutations in CLCN7 cause a severe form of recessive osteopetrosis (Kornak et al. 2001), whereas heterozygous missense mutations of CLCN7 cause autosomal dominant osteopetrosis (Balemans et al. 2005). Prompted by this observation, Pettersson et al. (2005) looked for evidence of an association between polymorphisms of CLCN7 and BMD in normal individuals and found that a common polymorphism in exon 15 of CLCN7 that results in a methionine-to-valine amino acid change was associated with BMD in normal women. Further studies will be required to determine if this polymorphism is functionally important and to replicate the observation in other populations.

\section{Vitamin D receptor (VDR)}

Vitamin D, through its principal bioactive form 1,25dihydroxyvitamin $\mathrm{D} 3\left[1,25-(\mathrm{OH})_{2} \mathrm{D}_{3}\right]$ plays a crucial role in bone metabolism. The action of $1,25-(\mathrm{OH})_{2} \mathrm{D}_{3}$ is mediated through a specific hormone-receptor (VDR) that regulates gene expression by forming a heterodimer with retinoic $\mathrm{X}$ receptor (RXR) that binds to vitamin $\mathrm{D}$ re- 
sponse elements in target genes. Mutations in VDR cause the syndrome of vitamin D-resistant rickets which is a recessive condition characterized by alopecia, hypocalcaemia, hypophosphatemia, and severe rickets, and is resistant to treatment with vitamin $\mathrm{D}$ and its active metabolites (Kristjansson et al. 1993). Targeted inactivation of the VDR gene in mice provides a phenocopy of the human syndrome (Bouillon et al. 2003), but when these mice are fed a diet rich in calcium and phosphorus to normalize serum calcium and PTH concentrations, they develop normally without bone anomalies. It therefore appears that the bone defects that result from VDR deficiency are due to malabsorption of calcium and phosphate by the intestine rather than absence of 1,25 $(\mathrm{OH})_{2} \mathrm{D}_{3}$ signaling in bone cells. The VDR was the first candidate gene to be studied in relation to osteoporosis, and most attention has focused on polymorphisms situated near the $3^{\prime}$ flank of VDR recognized by the restriction enzymes BsmI, ApaI, and TaqI. A recent retrospective meta-analysis of association studies that genotyped the BsmI polymorphism concluded that there was evidence of an association between spine BMD and the BsmI polymorphism, equivalent to $\sim 0.15 \mathrm{Z}$-score units between the BB genotype and the other genotypes (Thakkinstian et al. 2004). No association with femoral neck BMD was observed. Another polymorphism affecting exon 2 of VDR has been described that creates an alternative translational start site, resulting in the production of two isoforms of the VDR protein, which differ in length by three amino acids (Gross et al. 1997). This has been associated with BMD in some, but not other, populations, and functional studies of this polymorphism have yielded inconclusive results (Gross et al. 1998). A further polymorphism has been identified in the promoter of VDR at a binding site for the transcription factor Cdx-2, which has been associated with BMD in Japanese subjects and appears to be functional (Arai et al. 2001). This polymorphism has been associated with fracture in other populations, but not with BMD (Fang et al. 2003). The most comprehensive study of VDR alleles in relation to osteoporosis-related phenotypes was that of Fang et al. (2005), who conducted a large-scale study of haplotype tagging SNP of VDR in 6418 participants of the Rotterdam study. As the result of this analysis, the authors identified haplotype alleles in the promoter region and 3' untranslated region (UTR) that were associated with an increased risk of fracture. For a subgroup of individuals who carried risk alleles at both sites, the fracture risk was significantly increased by $48 \%$ when compared with control subjects. Functional studies also showed that the promoter haplotype that increased fracture risk was associated with reduced VDR expression in reporter assays, whereas the $3^{\prime}$ UTR risk haplotype was associated with increased degradation of VDR mRNA. The data would be consistent with a model whereby the combination of risk haplotypes results in a lower VDR mRNA level due to decreased transcription and increased degradation. Interestingly, the risk alleles for fracture identified in this study were not associated with differences in BMD. In view of this, the mechanism by which these polymorphisms predispose to fracture is unclear, although a possibility, alluded to by the authors, was through an effect on bone geometry. Although this was a large and well-conducted study, the risk estimates were modest, and if correction had been applied for all the combinations of haplotypes tested (and their interactions), the results would not have been significant.

\section{Collagen type I $\mathrm{I}$}

The gene encoding the $\alpha$ I chain of type I collagen (COLIA1) is an important functional candidate for the pathogenesis of osteoporosis, since type I collagen is the major protein of bone and since mutations in this gene cause the syndrome of osteogenesis imperfecta-a rare disease characterized by increased bone fragility and reduced BMD (Boyde et al. 1999). Previous research identified associations between BMD and polymorphisms within the proximal promoter of COLIA1 (Garcia-Giralt et al. 2002) and within the first intron of COLIA1 (Grant et al. 1996). Most research has focused on a polymorphism within intron 1 , which is situated at a binding site for the transcription factor $\mathrm{Sp} 1$. The COLIA1 Sp1-binding site polymorphism has been associated with various osteoporosis-related phenotypes, including bone density (Grant et al. 1996; Uitterlinden et al. 1998), fragility fractures (Grant et al. 1996; Uitterlinden et al. 1998), postmenopausal bone loss (Harris et al. 2000; MacDonald et al. 2001), bone geometry (Qureshi et al. 2001), bone quality (Mann et al. 2001), and bone mineralization (Stewart et al. 2005). Functional analysis has shown that the osteoporosis-associated T allele $\left(" \mathrm{~s}^{\prime \prime}\right)$ of the Sp1 polymorphism is associated with increased DNA-protein binding, increased transcription, and abnormally increased production of the COLIA1 mRNA and protein (Mann et al. 2001). It is thought that the resulting imbalance between the COLIA1 and COLIA2 chains contributes to impairment of bone strength and reduced bone mass in carriers of the $\mathrm{T}$ allele by subtly affecting bone mineralization (Stewart et al. 2005). Retrospective meta-analyses of published studies have concluded that carriage of the $\mathrm{T}$ allele is associated with reduced BMD at the lumbar spine and femoral neck and with vertebral fractures (Efstathiadou et al. 2001; Mann and Ralston 2003). Moreover, homozygotes for the $\mathrm{T}$ allele of the $\mathrm{Sp} 1$ polymorphism were recently found to be associated with BMD and incident vertebral fractures in a large prospective meta-analysis of $>20,000$ participants of the GENOMOS study (Ralston et al. 2006). In the GENOMOS study, however, the BMD association was only observed for homozygotes for the $\mathrm{T}$ allele, in contrast to previous studies where heterozygotes also showed a reduction in BMD (Mann and Ralston 2003). The association with vertebral fracture in GENOMOS was similar to previous reports and equivalent to a $40 \%$ increase in fracture risk for each copy of the $\mathrm{T}$ allele carried. Interestingly, the association between COLIA1 alleles and vertebral fracture reported in GENOMOS and other studies was not fully explained on the basis of reduced bone density, implying that the Sp1 allele also acts as a marker for bone quality. The 
promoter polymorphisms of COLIA1 are in strong linkage disequilibrium with the $\mathrm{Sp} 1$ polymorphism, and two studies have now suggested that an extended haplotype defined by the Sp1 polymorphism and other promoter polymorphism may exert stronger effects on BMD than the individual polymorphisms (Garcia-Giralt et al. 2002; Stewart et al. 2006). Evidence has been presented to suggest the promoter polymorphism at position -1663 interacts with the transcription factor NMP4, which plays a role in osteoblast differentiation by interacting with Smads (Garcia-Giralt et al. 2005). While a functional interaction has been reported between the -1663 and -1997 polymorphisms in regulating COLIA1 transcription (Garcia-Giralt et al. 2005), it is currently unclear whether the -1997 polymorphism is also at the site of transcription factor binding.

\section{Estrogen receptor $\alpha$}

The estrogen receptor $\alpha$, encoded by the ESR 1 gene, is another important functional candidate for the regulation of bone mass. A large number of investigators have looked for evidence of an association between ESR 1 alleles and BMD, mostly focusing on two polymorphisms within intron 1 recognized by the $\mathrm{XbaI}$ and PvuII restriction enzymes, and on a TA repeat in the promoter. Studies of ESR1 alleles in relation to BMD have yielded inconsistent results, possibly because most studies have been of small sample size and involved subjects of different ages, menopausal status, and ethnic backgrounds (Ioannidis et al. 2002). A meta-analysis of published studies showed evidence of an association between the XbaI polymorphisms and both BMD and fractures, with higher BMD values in "XX" homozygotes and a reduced risk of fractures in association with this genotype (Ioannidis et al. 2002). More recently, a prospective metaanalysis of data from $>18,000$ subjects in the GENOMOS study confirmed that "XX" homozygotes had a reduced risk of fracture (Ioannidis et al. 2004). In this study, no association with BMD was observed, indicating that ESR1 influences fracture risk independent of an effect on BMD. The mechanism responsible for this observation remains unclear, but one possibility may be an effect on bone quality, since ESR1 alleles have been associated with ultrasound properties of bone and bone loss (Albagha et al. 2005). There has been controversy as to whether the associations between BMD and polymorphisms in the 5' region of the ESR 1 gene are driven by the intron 1 polymorphisms or the TA repeat polymorphism in the ESR1 promoter. Previous studies have shown that the PvuII polymorphism lies within consensus recognition sites for the AP4 and Myb transcription factors; studies using promoter-reporter assays have shown that the PvuII polymorphism influences Mybdriven transcription in vitro (Herrington et al. 2002); and other studies have shown that both the XbaI and PvuII polymorphisms also influence reporter gene transcription in vitro (Maruyama et al. 2000). In this regard, it is of interest that the PvuII and XbaI polymorphisms are located within a region that is $70 \%-80 \%$ conserved in the human, mouse, and rat genomes, whereas the TA repeat polymorphism is not conserved to any significant extent across species. These data are consistent with a direct functional effect of the PvuII and XbaI polymorphisms on ESR1 gene transcription, but it remains possible that the intron 1 polymorphisms are simply in linkage disequilibrium (LD) with causal polymorphisms elsewhere in the ESR1 gene.

\section{Concluding remarks}

Many advances have been made in understanding the role of genetic factors in osteoporosis since publication of the first paper in the field in 1994 that showed a strong association between VDR alleles and BMD (Morrison et al. 1994). At this time it was believed that osteoporosis susceptibility would be determined by a few genes of major effect and that these would pave the way for specific targeted therapies and provide genetic markers to assess disease risk. It has now become clear that osteoporosis susceptibility is mediated by a large number of genetic variants of modest effect size. Although there remains a prospect that genotyping for these variants could help assess the risk of osteoporosis, or complications such as fracture, it is likely that tens, or hundreds, of informative variants would have to be tested to be of real diagnostic value. Since some of the genetic variants that predispose to osteoporosis seem to do so by mechanisms independent of BMD, it could be that these might be successfully combined with BMD measurements to improve risk assessment for complications of osteoporosis such as fragility fractures. At the present time, many common polymorphic variants of candidate genes have been identified that contribute to osteoporosis susceptibility in specific studies. Relatively few candidate gene polymorphisms have been validated by large-scale studies, however, and much work remains to be done to identify genetic variants that are consistently associated with osteoporosis-related phenotypes and to determine whether they will represent useful diagnostic tools and molecular targets for therapeutic manipulation.

\section{References}

Ai, M., Holmen, S.L., Van Hul, W., Williams, B.O., and Warman, M.L. 2005. Reduced affinity to and inhibition by DKK1 form a common mechanism by which high bone mass-associated missense mutations in LRP5 affect canonical Wnt signaling. Mol. Cell. Biol. 25: 4946-4955.

Albagha, O.M., Pettersson, U., Stewart, A., McGuigan, F.E., MacDonald, H.M., Reid, D.M., and Ralston, S.H. 2005. Association of oestrogen receptor $\alpha$ gene polymorphisms with postmenopausal bone loss, bone mass, and quantitative ultrasound properties of bone. J. Med. Genet. 42: 240-246.

Altmuller, J., Palmer, L.J., Fischer, G., Scherb, H., and Wjst, M. 2001. Genomewide scans of complex human diseases: True linkage is hard to find. Am. J. Hum. Genet. 69: 936-950.

Andrew, T., Antioniades, L., Scurrah, K.J., MacGregor, A.J., and Spector, T.D. 2005. Risk of wrist fracture in women is heritable and is influenced by genes that are largely independent of those influencing BMD. J. Bone Miner. Res. 20: 67-74. 
Arai, H., Miyamoto, K.I., Yoshida, M., Yamamoto, H., Taketani, Y., Morita, K., Kubota, M., Yoshida, S., Ikeda, M., Watabe, F., et al. 2001. The polymorphism in the caudal-related homeodomain protein Cdx-2 binding element in the human vitamin D receptor gene. J. Bone Miner. Res. 16: 1256-1264.

Arden, N.K. and Spector, T.D. 1997. Genetic influences on muscle strength, lean body mass, and bone mineral density: A twin study. J. Bone Miner. Res. 12: 2076-2081.

Arden, N.K., Baker, J., Hogg, C., Baan, K., and Spector, T.D. 1996. The heritability of bone mineral density, ultrasound of the calcaneus and hip axis length: A study of postmenopausal twins. J. Bone Miner. Res. 11: 530-534.

Babij, P., Zhao, W., Small, C., Kharode, Y., Yaworsky, P.J., Bouxsein, M.L., Reddy, P.S., Bodine, P.V., Robinson, J.A., Bhat, B., et al. 2003. High bone mass in mice expressing a mutant LRP5 gene. J. Bone Miner. Res. 18: 960-974.

Bafico, A., Liu, G., Yaniv, A., Gazit, A., and Aaronson, S.A. 2001. Novel mechanism of Wnt signalling inhibition mediated by Dickkopf-1 interaction with LRP6/Arrow. Nat. Cell Biol. 3: 683-686.

Balemans, W., Van Den Ende, J., Freire Paes-Alves, A., Dikkers, F.G., Willems, P.J., Vanhoenacker, F., Almeida-Melo, N., Alves, C.F., Stratakis, C.A., Hill, S.C., et al. 1999. Localization of the gene for sclerosteosis to the van Buchem diseasegene region on chromosome 17q12-q21. Am. J. Hum. Genet. 64: 1661-1669.

Balemans, W., Ebeling, M., Patel, N., Van Hul, E., Olson, P., Dioszegi, M., Lacza, C., Wuyts, W., Van Den Ende, J., Willems, P., et al. 2001. Increased bone density in sclerosteosis is due to the deficiency of a novel secreted protein (SOST). Hum. Mol. Genet. 10: 537-543.

Balemans, W., Foernzler, D., Parsons, C., Ebeling, M., Thompson, A., Reid, D.M., Lindpaintner, K., Ralston, S.H., and Van Hul, W. 2002a. Lack of association between the SOST gene and bone mineral density in perimenopausal women: Analysis of five polymorphisms. Bone 31: 515-519.

Balemans, W., Patel, N., Ebeling, M., Van Hul, E., Wuyts, W., Lacza, C., Dioszegi, M., Dikkers, F.G., Hildering, P., Willems, P.J., et al. 2002b. Identification of a $52 \mathrm{~kb}$ deletion downstream of the SOST gene in patients with van Buchem disease. J. Med. Genet. 39: 91-97.

Balemans, W., Van Wesenbeeck, L., and Van Hul, W. 2005. A clinical and molecular overview of the human osteopetroses. Calcif. Tissue Int. 77: 263-274.

Beamer, W.G., Shultz, K.L., Donahue, L.R., Churchill, G.A., Sen, S., Wergedal, J.R., Baylink, D.J., and Rosen, C.J. 2001. Quantitative trait loci for femoral and lumbar vertebral bone mineral density in $\mathrm{C} 57 \mathrm{BL} / 6 \mathrm{~J}$ and $\mathrm{C} 3 \mathrm{H} / \mathrm{HeJ}$ inbred strains of mice. J. Bone Miner. Res. 16: 1195-1206.

Beighton, P., Barnard, A., Hamersma, H., and van der Wouden, A. 1984. The syndromic status of sclerosteosis and van Buchem disease. Clin. Genet. 25: 175-181.

Benes, H., Weinstein, R.S., Zheng, W., Thaden, J.J., Jilka, R.L., Manolagas, S.C., and Shmookler Reis, R.J. 2000. Chromosomal mapping of osteopenia-associated quantitative trait loci using closely related mouse strains. J. Bone Miner. Res. 15: 626-633.

Bilezikian, J.P., Morishima, A., Bell, J., and Grumbach, M.M. 1998. Increased bone mass as a result of estrogen therapy in a man with aromatase deficiency. N. Engl. J. Med. 339: 599603.

Borton, A.J., Frederick, J.P., Datto, M.B., Wang, X.F., and Weinstein, R.S. 2001. The loss of Smad3 results in a lower rate of bone formation and osteopenia through dysregulation of osteoblast differentiation and apoptosis. J. Bone Miner. Res. 16:
$1754-1764$.

Bouillon, R., Van Cromphaut, S., and Carmeliet, G. 2003. Intestinal calcium absorption: Molecular vitamin D mediated mechanisms. J. Cell. Biochem. 88: 332-339.

Boyde, A., Travers, R., Glorieux, F.H., and Jones, S.J. 1999. The mineralization density of iliac crest bone from children with osteogenesis imperfecta. Calcif. Tissue Int. 64: 185-190.

Boyden, L.M., Mao, J., Belsky, J., Mitzner, L., Farhi, A., Mitnick, M.A., Wu, D., Insogna, K., and Lifton, R.P. 2002. High bone density due to a mutation in LDL-receptor-related protein 5. N. Engl. J. Med. 346: 1513-1521.

Brunkow, M., Gardner, J., Van Ness, J., Paeper, B., Kovacevich, B., Proll, S., Skonier, J., Zhao, L., Sabo, P., Fu, Y., et al. 2001. Bone dysplasia sclerosteosis results from loss of the sost gene product, a novel cystine knot-containing protein. Am. J. Hum. Genet. 68: 577-589.

Cao, X. and Chen, D. 2005. The BMP signaling and in vivo bone formation. Gene 357: 1-8.

Cardon, L.R. and Abecasis, G.R. 2003. Using haplotype blocks to map human complex trait loci. Trends Genet. 19: 135140.

Christian, J.C., Yu, P.L., Slemenda, C.W., and Johnston, C.C. 1989. Heritability of bone mass: A longitudinal study in aging male twins. Am. J. Hum. Genet. 44: 429-433.

Cong, F., Schweizer, L., and Varmus, H. 2004. Wnt signals across the plasma membrane to activate the $\beta$-catenin pathway by forming oligomers containing its receptors, Frizzled and LRP. Development 131: 5103-5115.

Cummings, S.R., Nevitt, M.C., Browner, W.S., Stone, K., Fox, K.M., Ensrud, K.E., Cauley, J., Black, D., and Vogt, T.M 1995. Risk factors for hip fracture in white women. Study of Osteoporotic Fractures Research Group. N. Engl. I. Med. 332: 767-773.

Deng, H.W., Chen, W.M., Recker, S., Stegman, M.R., Li, J.L., Davies, K.M., Zhou, Y., Deng, H., Heaney, R., and Recker, R.R. 2000. Genetic determination of Colles' fracture and differential bone mass in women with and without Colles' fracture. J. Bone Miner. Res. 15: 1243-1252.

De Robertis, E.M. and Kuroda, H. 2004. Dorsal-ventral patterning and neural induction in Xenopus embryos. Annu. Rev. Cell. Dev. Biol. 20: 285-308.

Doecke, J.D., Day, C.J., Stephens, A.S., Carter, S.L., van Daal, A., Kotowicz, M.A., Nicholson, G.C., and Morrison, N.A. 2006. Association of functionally different RUNX2 P2 promoter alleles with BMD. J. Bone Miner. Res. 21: 265-273.

Efstathiadou, Z., Tsatsoulis, A., and Ioannidis, J.P. 2001. Association of collagen I $\alpha 1 \mathrm{Sp} 1$ polymorphism with the risk of prevalent fractures: A meta-analysis. J. Bone Miner. Res. 16: 1586-1592.

Fang, Y., van Meurs, J.B., Bergink, A.P., Hofman, A., van Duijn, C.M., van Leeuwen, J.P., Pols, H.A., and Uitterlinden, A.G. 2003. Cdx-2 polymorphism in the promoter region of the human vitamin D receptor gene determines susceptibility to fracture in the elderly. J. Bone Miner. Res. 18: 1632-1641.

Fang, Y., van Meurs, J.B., d'Alesio, A., Jhamai, M., Zhao, H., Rivadeneira, F., Hofman, A., van Leeuwen, J.P., Jehan, F., Pols, H.A., et al. 2005. Promoter and 3'-untranslated-region haplotypes in the vitamin $\mathrm{D}$ receptor gene predispose to osteoporotic fracture: The Rotterdam study. Am. J. Hum. Genet. 77: 807-823.

Ferrari, S.L., Deutsch, S., Choudhury, U., Chevalley, T., Bonjour, J.P., Dermitzakis, E.T., Rizzoli, R., and Antonarakis, S.E. 2004. Polymorphisms in the low-density lipoprotein receptor-related protein 5 (LRP5) gene are associated with variation in vertebral bone mass, vertebral bone size, and 
stature in whites. Am. J. Hum. Genet. 74: 866-875.

Frattini, A., Orchard, P.J., Sobacchi, C., Giliani, S., Abinun, M., Mattsson, J.P., Keeling, D.J., Andersson, A.K., Wallbrandt, P., Zecca, L., et al. 2000. Defects in TCIRG1 subunit of the vacuolar proton pump are responsible for a subset of human autosomal recessive osteopetrosis. Nat. Genet. 25: 343-346.

Garcia-Giralt, N., Nogues, X., Enjuanes, A., Puig, J., Mellibovsky, L., Bay-Jensen, A., Carreras, R., Balcells, S., DiezPerez, A., and Grinberg, D. 2002. Two new single nucleotide polymorphisms in the COLIA1 upstream regulatory region and their relationship with bone mineral density. I. Bone Miner. Res. 17: 384-393.

Garcia-Giralt, N., Enjuanes, A., Bustamante, M., Mellibovsky, L., Nogues, X., Carreras, R., Ez-Perez, A., Grinberg, D., and Balcells, S. 2005. In vitro functional assay of alleles and haplotypes of two COL1A1-promoter SNPs. Bone 36: 902-908.

Gardner, J.C., van Bezooijen, R.L., Mervis, B., Hamdy, N.A., Lowik, C.W., Hamersma, H., Beighton, P., and Papapoulos, S.E. 2005. Bone mineral density in sclerosteosis; affected individuals and gene carriers. J. Clin. Endocrinol. Metab. 90: 6392-6395.

Geiser, A.G., Zeng, Q.Q., Sato, M., Helvering, L.M., Hirano, T., and Turner, C.H. 1998. Decreased bone mass and bone elasticity in mice lacking the transforming growth factor- $\beta 1$ gene. Bone 23: 87-93.

Gelb, B.D., Shi, G.P., Chapman, H.A., and Desnick, R.J. 1996. Pycnodysostosis, a lysosomal disease caused by cathepsin $\mathrm{K}$ deficiency. Science 273: 1236-1238.

Ghadami, M., Makita, Y., Yoshida, K., Nishimura, G., Fukushima, Y., Wakui, K., Ikegawa, S., Yamada, K., Kondo, S., Niikawa, N., et al. 2000. Genetic mapping of the CamuratiEngelmann disease locus to chromosome 19q13.1-q13.3. Am. J. Hum. Genet. 66: 143-147.

Gianfrancesco, F., Esposito, T., Ombra, M.N., Forabosco, P., Maninchedda, G., Fattorini, M., Casula, S., Vaccargiu, S., Casu, G., Cardia, F., et al. 2003. Identification of a novel gene and a common variant associated with uric acid nephrolithiasis in a Sardinian genetic isolate. Am. J. Hum. Genet. 72: 1479-1491.

Giraudeau, F.S., McGinnis, R.E., Gray, I.C., O’Brien, E.J., Doncaster, K.E., Spurr, N.K., Ralston, S.H., Reid, D.M., and Wood, J. 2004. Characterization of common genetic variants in cathepsin $\mathrm{K}$ and testing for association with bone mineral density in a large cohort of perimenopausal women from Scotland. J. Bone Miner. Res. 19: 31-41.

Gong, Y., Vikkula, M., Boon, L., Lui, J., Beighton, P., Ramesar, R., Peltonen, L., Somer, H., Hirose, T., Dallapicola, B., et al. 1998. Osteoporosis-pseudoglioma syndrome, a disorder affecting skeletal strength and vision, is assigned to chromosome region 11q12-13. Am. J. Hum. Genet. 1996: 146-151.

Gong, Y., Slee, R.B., Fukai, N., Rawadi, G., Roman-Roman, S., Reginato, A.M., Wang, H., Cundy, T., Glorieux, F.H., Lev, D., et al. 2001. LDL receptor-related protein 5 (LRP5) affects bone accrual and eye development. Cell 107: 513-523.

Grant, S.F.A., Reid, D.M., Blake, G., Herd, R., Fogelman, I., and Ralston, S.H. 1996. Reduced bone density and osteoporosis associated with a polymorphic Sp1 site in the collagen type I $\alpha 1$ gene. Nat. Genet. 14: 203-205.

Gretarsdottir, S., Thorleifsson, G., Reynisdottir, S.T., Manolescu, A., Jonsdottir, S., Jonsdottir, T., Gudmundsdottir, T., Bjarnadottir, S.M., Einarsson, O.B., Gudjonsdottir, H.M., et al. 2003. The gene encoding phosphodiesterase 4D confers risk of ischemic stroke. Nat. Genet. 35: 131-138.

Gross, C., Eccleshall, T.R., Malloy, P.J., Villa, M.L., Marcus, R., and Feldman, D. 1997. The presence of a polymorphism at the translation initiation site of the vitamin $\mathrm{D}$ receptor gene is associated with low bone mineral density in postmenopausal Mexican-American women. J. Bone Miner. Res. 12: $1850-1856$.

Gross, C., Krishnan, A.V., Malloy, P.J., Eccleshall, T.R., Zhao, X.Y., and Feldman, D. 1998. The vitamin D receptor gene start codon polymorphism: A functional analysis of FokI variants. J. Bone Miner. Res. 13: 1691-1699.

Gueguen, R., Jouanny, P., Guillemin, F., Kuntz, C., Pourel, J., and Siest, G. 1995. Segregation analysis and variance components analysis of bone mineral density in healthy families. J. Bone Miner. Res. 12: 2017-2022.

Harris, S.S., Patel, M.S., Cole, D.E., and Dawson-Hughes, B. 2000. Associations of the collagen type I $\alpha 1$ Spl polymorphism with five-year rates of bone loss in older adults. Calcif. Tissue Int. 66: 268-271.

Hernandez, M.V., Peris, P., Guanabens, N., Alvarez, L., Monegal, A., Pons, F., Ponce, A., and Munoz-Gomez, J. 1997. Biochemical markers of bone turnover in Camurati-Engelmann disease: A report on four cases in one family. Calcif. Tissue Int. 61: 48-51.

Herrington, D.M., Howard, T.D., Brosnihan, K.B., McDonnell, D.P., Li, X., Hawkins, G.A., Reboussin, D.M., Xu, J., Zheng, S.L., Meyers, D.A., et al. 2002. Common estrogen receptor polymorphism augments effects of hormone replacement therapy on E-selectin but not C-reactive protein. Circulation 105: 1879-1882.

Holmen, S.L., Giambernardi, T.A., Zylstra, C.R., Buckner-Berghuis, B.D., Resau, J.H., Hess, J.F., Glatt, V., Bouxsein, M.L., Ai, M., Warman, M.L., et al. 2004. Decreased BMD and limb deformities in mice carrying mutations in both Lrp5 and Lrp6. J. Bone Miner. Res. 19: 2033-2040.

Hunter, D., de Lange, M., Snieder, H., MacGregor, A.J., Swaminathan, R., Thakker, R.V., and Spector, T.D. 2001. Genetic contribution to bone metabolism, calcium excretion, and vitamin $\mathrm{D}$ and parathyroid hormone regulation. J. Bone Miner. Res. 16: 371-378.

Ichikawa, S., Koller, D.L., Johnson, M.L., Lai, D., Xuei, X., Edenberg, H.J., Klein, R.F., Orwoll, E.S., Hui, S.L., Foroud, T.M., et al. 2006. Human ALOX12, but not ALOX15, is associated with BMD in white men and women. J. Bone Miner. Res. 21: $556-564$

Ioannidis, J.P. 2003. Genetic associations: False or true? Trends Mol. Med. 9: 135-138.

Ioannidis, J.P., Stavrou, I., Trikalinos, T.A., Zois, C., Brandi, M.L., Gennari, L., Albagha, O., Ralston, S.H., and Tsatsoulis, A. 2002. Association of polymorphisms of the estrogen receptor $\alpha$ gene with bone mineral density and fracture risk in women: A meta-analysis. J. Bone Miner. Res. 17: 2048-2060.

Ioannidis, J.P., Ralston, S.H., Bennett, S.T., Brandi, M.L., Grinberg, D., Karassa, F.B., Langdahl, B., van Meurs, J.B., Mosekilde, L., Scollen, S., et al. 2004. Differential genetic effects of ESR1 gene polymorphisms on osteoporosis outcomes. JAMA 292: 2105-2114.

Janssens, K. and Van Hul, W. 2002. Molecular genetics of too much bone. Hum. Mol. Genet. 11: 2385-2393.

Janssens, K., Gershoni-Baruch, R., Guanabens, N., Migone, N., Ralston, S., Bonduelle, M., Lissens, W., Van Maldergem, L., Vanhoenacker, F., Verbruggen, L., et al. 2000a. Mutations in the gene encoding the latency-associated peptide of TGF- $\beta 1$ cause Camurati-Engelmann disease. Nat. Genet. 26: 273 275.

Janssens, K., Gershoni-Baruch, R., Van Hul, E., Brik, R., Guanabens, N., Migone, N., Verbruggen, L.A., Ralston, S.H., Bonduelle, M., Van Maldergem, L., et al. 2000b. Localisation of 
the gene causing diaphyseal dysplasia Camurati-Engelmann to chromosome 19q13. J. Med. Genet. 37: 245-249.

Janssens, K., ten Dijke, P., Ralston, S.H., Bergmann, C., and Van Hul, W. 2003. Transforming growth factor- $\beta 1$ mutations in Camurati-Engelmann disease lead to increased signaling by altering either activation or secretion of the mutant protein. J. Biol. Chem. 278: 7718-7724.

Johnson, M.L., Gong, G., Kimberling, W., Recker, S., Kimmel, D.B., and Recker, R.R. 1997. Linkage of a gene causing high bone mass to human chromosome 11 (11q12-13). Am. J. Hum. Genet. 60: 1326-1332.

Johnson, M.L., Harnish, K., Nusse, R., and Van Hul, W. 2004. LRP5 and Wnt signaling: A union made for bone. J. Bone Miner. Res. 19: 1749-1757.

Kanis, J.A., Melton III, L.J., Christiansen, C., Johnston, C.C., and Khaltaev, N. 1994. The diagnosis of osteoporosis. I. Bone Miner. Res. 9: 1137-1141.

Kannus, P., Palvanen, M., Kaprio, J., Parkkari, J., and Koskenvuo, M. 1999. Genetic factors and osteoporotic fractures in elderly people: Prospective 25 year follow up of a nationwide cohort of elderly Finnish twins. BMJ 319: 1334-1337.

Kaprio, J., Rimpela, A., Winter, T., Viken, R.J., Rimpela, M., and Rose, R.J. 1995. Common genetic influences on BMI and age at menarche. Hum. Biol. 67: 739-753.

Kato, M., Patel, M.S., Levasseur, R., Lobov, I., Chang, B.H., Glass, D.A., Hartmann, C., Li, L., Hwang, T.H., Brayton, C.F., et al. 2002. Cbfal-independent decrease in osteoblast proliferation, osteopenia, and persistent embryonic eye vascularization in mice deficient in Lrp5, a Wnt coreceptor. J. Cell Biol. 157: 303-314.

Kawano, Y. and Kypta, R. 2003. Secreted antagonists of the Wnt signalling pathway. J. Cell Sci. 116: 2627-2634.

Kelly, P.J., Nguyen, T., Hopper, J., Pocock, N., Sambrook, P., and Eisman, J. 1993. Changes in axial bone density with age: A twin study. J. Bone Miner. Res. 8: 11-17.

Kinoshita, A., Saito, T., Tomita, H., Makita, Y., Yoshida, K., Ghadami, M., Yamada, K., Kondo, S., Ikegawa, S., Nishimura, G., et al. 2000. Domain-specific mutations in TGFB1 result in Camurati-Engelmann disease. Nat. Genet. 26: 1920.

Klein, R.F., Allard, J., Avnur, Z., Nikolcheva, T., Rotstein, D., Carlos, A.S., Shea, M., Waters, R.V., Belknap, J.K., Peltz, G., et al. 2004. Regulation of bone mass in mice by the lipoxygenase gene Alox15. Science 303: 229-232.

Koh, J.M., Jung, M.H., Hong, J.S., Park, H.J., Chang, J.S., Shin, H.D., Kim, S.Y., and Kim, G.S. 2004. Association between bone mineral density and LDL receptor-related protein 5 gene polymorphisms in young Korean men. J. Korean Med. Sci. 19: 407-412.

Koller, D.L., White, K.E., Liu, G., Hui, S.L., Conneally, P.M., Johnston, C.C., Econs, M.J., Foroud, T., and Peacock, M. 2003. Linkage of structure at the proximal femur to chromosomes 3, 7, 8, and 19. J. Bone Miner. Res. 18: 1057-1065.

Komori, T., Yagi, H., Nomura, S., Yamaguchi, A., Sasaki, K., Deguchi, K., Shimuzu, Y., Bronson, R.T., Gao, Y.-H., Inada, M., et al. 1997. Targeted disruption of Cbfal results in a complete lack of bone formation owing to maturational arrest of osteoblasts. Cell 89: 755-764.

Kornak, U., Kasper, D., Bosl, M.R., Kaiser, E., Schweizer, M., Schulz, A., Friedrich, W., Delling, G., and Jentsch, T.J. 2001. Loss of the ClC-7 chloride channel leads to osteopetrosis in mice and man. Cell 104: 205-215.

Krall, E.A. and Dawson-Hughes, B. 1993. Heritable and life-style determinants of bone mineral density. J. Bone Miner. Res. 8: $1-9$.
Kristjansson, K., Rut, A.R., Hewison, M., O'Riordan, J.L., and Hughes, M.R. 1993. Two mutations in the hormone binding domain of the vitamin $\mathrm{D}$ receptor cause tissue resistance to 1,25 dihydroxyvitamin D3. J. Clin. Invest. 92: 12-16.

Langdahl, B.L., Knudsen, J.Y., Jensen, H.K., Gregersen, N., and Eriksen, E.F. 1997. A sequence variation: 713-8delC in the transforming growth factor- $\beta 1$ gene has higher prevalence in osteoporotic women than in normal women and is associated with very low bone mass in osteoporotic women and increased bone turnover in both osteoporotic and normal women. Bone 20: 289-294.

Langdahl, B.L., Carstens, M., Stenkjaer, L., and Eriksen, E.F. 2003. Polymorphisms in the transforming growth factor $\beta 1$ gene and osteoporosis. Bone 32: 297-310.

Lee, B., Thirunavukkarasu, K., Zhou, L., Pastore, L., Baldini, A., Hecht, J., Geoffroy, V., Ducy, P., and Karsenty, G. 1997. Missense mutations abolishing DNA binding of the osteoblastspecific transcription factor OSF2/CBFA1 in cleidocranial dysplasia. Nat. Genet. 16: 307-310.

Li, X., Zhang, Y., Kang, H., Liu, W., Liu, P., Zhang, J., Harris, S.E., and Wu, D. 2005. Sclerostin binds to LRP5/6 and antagonizes canonical Wnt signaling. J. Biol. Chem. 280: 19883-19887.

Little, R.D., Carulli, J.P., Del Mastro, R.G., Dupuis, J., Osborne, M., Folz, C., Manning, S.P., Swain, P.M., Zhao, S.C., Eustace, B., et al. 2002. A mutation in the LDL receptor-related protein 5 gene results in the autosomal dominant high-bonemass trait. Am. J. Hum. Genet. 70: 11-19.

Liu, Y.Z., Liu, Y.J., Recker, R.R., and Deng, H.W. 2003. Molecular studies of identification of genes for osteoporosis: The 2002 update. J. Endocrinol. 177: 147-196.

Lohmueller, K.E., Pearce, C.L., Pike, M., Lander, E.S., and Hirschhorn, J.N. 2003. Meta-analysis of genetic association studies supports a contribution of common variants to susceptibility to common disease. Nat. Genet. 33: 177-182.

Loots, G.G., Kneissel, M., Keller, H., Baptist, M., Chang, J., Collette, N.M., Ovcharenko, D., Plajzer-Frick, I., and Rubin, E.M. 2005. Genomic deletion of a long-range bone enhancer misregulates sclerostin in van Buchem disease. Genome Res. 15: 928-935.

MacDonald, H.M., McGuigan, F.E.A., New, S.A., Campbell, M.K., Golden, M.H., Ralston, S.H., and Reid, D.M. 2001. COL1A1 Sp1 polymorphism predicts perimenopausal and early postmenopausal spinal bone loss. J. Bone Miner. Res. 16: $1634-1641$.

Mann, V. and Ralston, S.H. 2003. Meta-analysis of COL1A1 Sp1 polymorphism in relation to bone mineral density and osteoporotic fracture. Bone 32: 711-717.

Mann, V., Hobson, E.E., Li, B., Stewart, T.L., Grant, S.F., Robins, S.P., Aspden, R.M., and Ralston, S.H. 2001. A COL1A1 Sp1 binding site polymorphism predisposes to osteoporotic fracture by affecting bone density and quality. J. Clin. Invest. 107: 899-907.

Mao, B. and Niehrs, C. 2003. Kremen2 modulates Dickkopf2 activity during Wnt/LRP6 signaling. Gene 302: 179-183.

Mao, B., Wu, W., Davidson, G., Marhold, J., Li, M., Mechler, B.M., Delius, H., Hoppe, D., Stannek, P., Walter, C., et al. 2002. Kremen proteins are Dickkopf receptors that regulate Wnt/ $\beta$-catenin signalling. Nature 417: 664-667.

Maruyama, H., Toji, H., Harrington, C.R., Sasaki, K., Izumi, Y., Ohnuma, T., Arai, H., Yasuda, M., Tanaka, C., Emson, P.C., et al. 2000. Lack of an association of estrogen receptor $\alpha$ gene polymorphisms and transcriptional activity with Alzheimer disease. Arch. Neurol. 57: 236-240.

Massagué, J. and Chen, Y.G. 2000. Controlling TGF- $\beta$ signaling. 
Genes \& Dev. 14: 627-644.

Michaelsson, K., Melhus, H., Ferm, H., Ahlbom, A., and Pedersen, N.L. 2005. Genetic liability to fractures in the elderly. Arch. Intern. Med. 165: 1825-1830.

Morrison, N.A., Qi, J.C., Tokita, A., Kelly, P., Crofts, L., Nguyen, T.V., Sambrook, P.N., and Eisman, J.A. 1994. Prediction of bone density from vitamin $\mathrm{D}$ receptor alleles. $\mathrm{Na}$ ture 367: 284-287.

Mundlos, S., Otto, F., Mundlos, C., Mulliken, J.B., Aylsworth, A.S., Albright, S., Lindhout, D., Cole, W.G., Henn, W., Knoll, J.H., et al. 1997. Mutations involving the transcription factor CBFA1 cause cleidocranial dysplasia. Cell 89: 773-779.

Orwoll, E.S., Belknap, J.K., and Klein, R.F. 2001. Gender specificity in the genetic determinants of peak bone mass. J. Bone Miner. Res. 16: 1962-1971.

Otto, F., Thornell, A.P., Crompton, T., Denzel, A., Gilmour, K.C., Rosewell, I.R., Stamp, G.W., Beddington, R.S., Mundlos, S., Olsen, B.R., et al. 1997. Cbfal, a candidate gene for cleidocranial dysplasia syndrome, is essential for osteoblast differentiation and bone development.. Cell 89: 765-771.

Pettersson, U., Albagha, O.M., Mirolo, M., Taranta, A., Frattini, A., McGuigan, F.E., Vezzoni, P., Teti, A., Van Hul, W., Reid, D.M., et al. 2005. Polymorphisms of the CLCN7 gene are associated with BMD in women. I. Bone Miner. Res. 20: 1960-1967.

Pocock, N.A., Eisman, J.A., Hopper, J.L., Yeates, M.G., Sambrook, P.N., and Eberl, S. 1987. Genetic determinants of bone mass in adults: A twin study. J. Clin. Invest. 80: 706710.

Quack, I., Vonderstrass, B., Stock, M., Aylsworth, A.S., Becker, A., Brueton, L., Lee, P.J., Majewski, F., Mulliken, J.B., Suri, M., et al. 1999. Mutation analysis of core binding factor A1 in patients with cleidocranial dysplasia. Am. J. Hum. Genet. 65: $1268-1278$

Qureshi, A.M., McGuigan, F.E.A., Seymour, D.G., Hutchison, J.D., Reid, D.M., and Ralston, S.H. 2001. Association between COLIA1 Sp1 alleles and femoral neck geometry. Calcif. Tissue Int. 69: 67-72.

Ralston, S.H. 2005. Genetic determinants of osteoporosis. Curr. Opin. Rheumatol. 17: 475-479.

Ralston, S.H., Uitterlinden, A.G., Brandi, M.L., Balcells, S., Langdahl, B.L., Lips, P., Lorenc, R., Obermayer-Pietsch, B., Scollen, S., Bustamante, M., et al. 2006. Large-scale evidence for the effect of the COLIA1 Sp1 polymorphism on osteoporosis outcomes: The GENOMOS study. PLoS Med. 3: e90.

Ramesh, B.L., Wilson, S.G., Dick, I.M., Islam, F.M., Devine, A., and Prince, R.L. 2005. Bone mass effects of a BMP4 gene polymorphism in postmenopausal women. Bone 36: 555561.

Rogers, J., Mahaney, M.C., Beamer, W.G., Donahue, L.R., and Rosen, C.J. 1997. Beyond one gene-one disease: Alternative strategies for deciphering genetic determinants of osteoporosis. Calcif. Tissue Int. 60: 225-228.

Sawcer, S.J., Maranian, M., Singlehurst, S., Yeo, T., Compston, A., Daly, M.J., De Jager, P.L., Gabriel, S., Hafler, D.A., Ivinson, A.J., et al. 2004. Enhancing linkage analysis of complex disorders: An evaluation of high-density genotyping. Hum. Mol. Genet. 13: 1943-1949.

Seemann, P., Schwappacher, R., Kjaer, K.W., Krakow, D., Lehmann, K., Dawson, K., Stricker, S., Pohl, J., Ploger, F., Staub, E., et al. 2005. Activating and deactivating mutations in the receptor interaction site of GDF5 cause symphalangism or brachydactyly type A2. J. Clin. Invest. 115: 23732381.

Semenov, M., Tamai, K., and He, X. 2005. SOST is a ligand for
LRP5/LRP6 and a Wnt signaling inhibitor. I. Biol. Chem. 280: 26770-26775.

Smith, D.M., Nance, W.E., Kang, K.W., Christian, J.C., and Johnston, C.C. 1973. Genetic factors in determining bone mass. J. Clin. Invest. 52: 2800-2808.

Snieder, H., MacGregor, A.J., and Spector, T.D. 1998. Genes control the cessation of a woman's reproductive life: A twin study of hysterectomy and age at menopause. J. Clin. Endocrinol. Metab. 83: 1875-1880.

Sobacchi, C., Vezzoni, P., Reid, D.M., McGuigan, F.E., Frattini, A., Mirolo, M., Albhaga, O.M., Musio, A., Villa, A., and Ralston, S.H. 2004. Association between a polymorphism affecting an AP1 binding site in the promoter of the TCIRG1 gene and bone mass in women. Calcif. Tissue Int. 74: 35-41.

Stewart, T.L., Roschger, P., Misof, B.M., Mann, V., Fratzl, P., Klaushofer, K., Aspden, R.M., and Ralston, S.H. 2005. Association of COLIA1 Sp1 alleles with defective bone nodule formation in vitro and abnormal bone mineralisation in vivo. Calcif. Tissue Int. 77: 113-118.

Stewart, T.L., Jin, H., McGuigan, F.E., Albagha, O.M., GarciaGiralt, N., Bassiti, A., Grinberg, D., Balcells, S., Reid, D.M., and Ralston, S.H. 2006. Haplotypes defined by promoter and intron 1 polymorphisms of the COLIA1 gene regulate bone mineral density in women. J. Clin. Endocrinol. Metab. (in press).

Styrkarsdottir, U., Cazier, J.-B., Kong, A., Rolfsson, O., Larsen, H., Bjarnadottir, E., Johannsdottir, V.D., Sigurdardottir, M.S., Bagger, Y., Christiansen, C., et al. 2003. Linkage of osteoporosis to chromosome 20p12 and association to BMP2. PLoS Biol. 1: E69.

Thakkinstian, A., D'Este, C., Eisman, J., Nguyen, T., and Attia, J. 2004. Meta-analysis of molecular association studies: Vitamin D receptor gene polymorphisms and BMD as a case study. J. Bone Miner. Res. 19: 419-428.

Torgerson, D.J., Campbell, M.K., Thomas, R.E., and Reid, D.M. 1996. Prediction of perimenopausal fractures by bone mineral density and other risk factors. J. Bone Miner. Res. 11: 293-297.

Turner, C.H., Sun, Q., Schriefer, J., Pitner, N., Price, R., Bouxsein, M.L., Rosen, C.J., Donahue, L.R., Shultz, K.L., and Beamer, W.G. 2003. Congenic mice reveal sex-specific genetic regulation of femoral structure and strength. Calcif. Tissue Int. 73: 297-303.

Uitterlinden, A.G., Burger, H., Huang, Q., Yue, F., McGuigan, F.E.A., Grant, S.F.A., Hofman, A., van Leeuwen, J.P.T.M., Pols, H.A.P., and Ralston, S.H. 1998. Relation of alleles of the collagen type I $\alpha 1$ gene to bone density and risk of osteoporotic fractures in postmenopausal women. N. Engl. J. Med. 338: 1016-1022.

Uitterlinden, A.G., Arp, P.P., Paeper, B.W., Charmley, P., Proll, S., Rivadeneira, F., Fang, Y., van Meurs, J.B., Britschgi, T.B., Latham, J.A., et al. 2004. Polymorphisms in the sclerosteosis/van Buchem disease gene (SOST) region are associated with bone-mineral density in elderly whites. Am. J. Hum. Genet. 75: 1032-1045.

Urano, T., Shiraki, M., Ezura, Y., Fujita, M., Sekine, E., Hoshino, S., Hosoi, T., Orimo, H., Emi, M., Ouchi, Y., et al. 2004. Association of a single-nucleotide polymorphism in lowdensity lipoprotein receptor-related protein 5 gene with bone mineral density. J. Bone Miner. Metab. 22: 341-345.

van Bezooijen, R.L., Roelen, B.A., Visser, A., Wee-Pals, L., de Wilt, E., Karperien, M., Hamersma, H., Papapoulos, S.E., ten Dijke, P., and Lowik, C.W. 2004. Sclerostin is an osteocyteexpressed negative regulator of bone formation, but not a classical BMP antagonist. J. Exp. Med. 199: 805-814. 
Van Hul, W., Balemans, W., Van Hul, E., Dikkers, F.G., Obee, H., Stokroos, R.J., Hildering, P., Vanhoenacker, F., Van Camp, G., and Willems, P.J. 1998. Van Buchem disease (hyperostosis corticalis generalisata) maps to chromosome 17q12-q21. Am. J. Hum. Genet. 62: 391-399.

van Meurs, J.B., Rivadeneira, F., Jhamai, M., Hugens, W., Hofman, A., van Leeuwen, J.P., Pols, H.A., and Uitterlinden, A.G. 2006. Common genetic variation of the low-density lipoprotein receptor-related protein 5 and 6 genes determines fracture risk in elderly white men. J. Bone Miner. Res. 21: 141-150.

Van Wesenbeeck, L., Cleiren, E., Gram, J., Beals, R.K., Benichou, O., Scopelliti, D., Key, L., Renton, T., Bartels, C., Gong, Y., et al. 2003. Six novel missense mutations in the LDL receptor-related protein 5 (LRP5) gene in different conditions with an increased bone density. Am. J. Hum. Genet. 72: 763-771.

Vaughan, T., Pasco, J.A., Kotowicz, M.A., Nicholson, G.C., and Morrison, N.A. 2002. Alleles of RUNX2/CBFA1 gene are associated with differences in bone mineral density and risk of fracture. J. Bone Miner. Res. 17: 1527-1534.

Vaughan, T., Reid, D.M., Morrison, N.A., and Ralston, S.H. 2004. RUNX2 alleles associated with BMD in Scottish women; interaction of RUNX2 alleles with menopausal status and body mass index. Bone 34: 1029-1036.

Wilson, S.G., Reed, P.W., Bansal, A., Chiano, M., Lindersson, M., Langdown, M., Prince, R.L., Thompson, D., Thompson, E., Bailey, M., et al. 2003. Comparison of genome screens for two independent cohorts provides replication of suggestive linkage of bone mineral density to $3 \mathrm{p} 21$ and $1 \mathrm{p} 36$. Am. J. Hum. Genet. 72: 144-155.

Wilson, S.G., Reed, P.W., Andrew, T., Barber, M.J., Lindersson, M., Langdown, M., Thompson, D., Thompson, E., Bailey, M., Chiano, M., et al. 2004. A genome-screen of a large twin cohort reveals linkage for quantitative ultrasound of the calcaneus to 2q33-37 and 4q12-21. J. Bone Miner. Res. 19: 270277.

Winkler, D.G., Sutherland, M.K., Geoghegan, J.C., Yu, C., Hayes, T., Skonier, J.E., Shpektor, D., Jonas, M., Kovacevich, B.R., Staehling-Hampton, K., et al. 2003. Osteocyte control of bone formation via sclerostin, a novel BMP antagonist. EMBO J. 22: 6267-6276.

Winkler, D.G., Sutherland, M.S., Ojala, E., Turcott, E., Geoghegan, J.C., Shpektor, D., Skonier, J.E., Yu, C., and Latham, J.A. 2005. Sclerostin inhibition of Wnt-3a-induced C3H10T1/2 cell differentiation is indirect and mediated by bone morphogenetic proteins. J. Biol. Chem. 280: 2498-2502.

Yamada, Y., Hosoi, T., Makimoto, F., Tanaka, H., Seino, Y., and Ikeda, K. 1999. Transforming growth factor $\beta$-1 gene polymorphism and bone mineral density in Japanese adolescents. Am. J. Med. 106: 477-479.

Yamada, Y., Miyauchi, A., Takagi, Y., Tanaka, M., Mizuno, M., and Harada, A. 2001. Association of the C-509 $\rightarrow$ T polymorphism, alone of in combination with the T869 $\rightarrow$ C polymorphism, of the transforming growth factor- $\beta 1$ gene with bone mineral density and genetic susceptibility to osteoporosis in Japanese women. J. Mol. Med. 79: 149-156. 


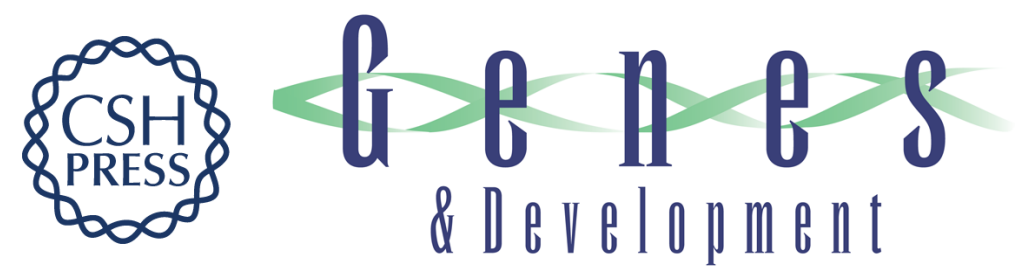

\section{Genetic regulation of bone mass and susceptibility to osteoporosis}

Stuart H. Ralston and Benoit de Crombrugghe

Genes Dev. 2006, 20:

Access the most recent version at doi:10.1101/gad.1449506

References This article cites 132 articles, 20 of which can be accessed free at: http://genesdev.cshlp.org/content/20/18/2492.full.html\#ref-list-1

License

Email Alerting Receive free email alerts when new articles cite this article - sign up in the box at the top Service right corner of the article or click here.

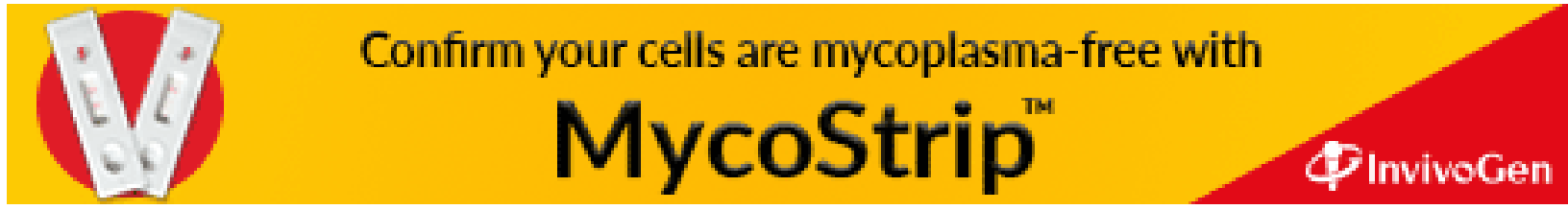

